\title{
Designing Web-based GIS Application by CSF Method: A Case Study in Boven Digoel Papua
}

\author{
Hendrykus Saritangdan Letsoin ${ }^{1}$, Albertus Joko Santoso ${ }^{1}$, and Suyoto ${ }^{1}$ \\ ${ }^{1}$ Magister Informatics Engineering. Universitas Atma Jaya Yogyakarta, Yogyakarta, Indonesia 55281
}

\begin{abstract}
Since Boven Digoel Regency was established in 2003, to this day its infrastructures are very limited, the region is still not developed, Human Resources (SDM) and Information and Communication Technology are still manual. The development of Geographic Information System was expected to contribute to ICT development in Papua, particularly Boven Digoel Regency, in displaying data of existing local potentials, e.g. tourism, plantation and forestry. Critical Success Factor Method was the right method in considering factors determining the success of the implementation of a strategy, in good information management and in providing data of local potentials of geographic information system for people in Boven Digoel Regency and the people of Indonesia in general to introduce Boven Digoel Regency, Papua. Framework Laravel with PHP programming language was expected to support Geographic Information System well to determine the distribution of local potentials in Boven Digoel Regency..
\end{abstract}

\section{Introduction}

As a new government center since 2003, Boven Digoel face several complex issues which are also experienced by newly formed regencies and. The main issue which becomes principle of policy implementation and government management is adjustment of local income (Locally-generated Revenue) and needs which emerge and must be fulfilled especially for the society as a form of public accountability. With the background of being a former prison camp, Boven Digoel is the only region in Papua or even Indonesia which has rapid development, growth and expansion in various sectors. With extensive local potentials, GIS application was made to help getting information to be processed, stored and displayed by location on the application in writing, color, picture and direction. Therefore, GIS application users can easily get information they need.

According to T. A. N. Xiaoshan and S. Yizhong (2010), geographic Information System is very important to get better display and also present map between user and computer. The Geographic Information System (GIS) in this study in synchronized in (GIS) map [1] in assessing a region for different energy potential affected by various technical, topographical and environmental variables. The study by A. Oudin (2017) discussed modeling of different obstacles for the latest energy potentials and result visualization on an interactive map. Geographic Information System (GIS) is used in various regions to assess a location and its situation [2]. According to L. Wang, et.al. (2010), a new geographic information technology application can be demonstrated in government using "Geo-Windows" as the Geographic Information System (GIS) software for E-Government to be applied in the network [3]. The study by A. V. Vitianingsih and D. Cahyono (2016) state that without adequate road construction, traffic will exceed road volume capacity. It will make roads difficult to pass, causing risk of congestion and traffic accident. This paper will discuss the usage of Geographic Information System (GIS) in analyzing spatial data and attribute date (geoprocessing layers) in mapping accident-prone roads and mapping heavy traffic roads as alternatives for constructing new roads [4]. Geographic Information System (GIS) substantially defied existing method by relational data since the navigational operation of GIS map (e.g. panning, zooming in / out) has their own unique access patterns vastly different from relational equivalents. This study presents an efficient spatial caching framework in handling spatial object adjusted to navigational operational map so that density is visible in the system or GIS application so that application user can travel to their destination [5].

The current development of internet technology, according to, N. Hakim, Maulana and R. Cahyana (2015), is very rapid so everyone should use it to access information, whether via internet media or other social media, e.g. Facebook, Instagram, Youtube, etc. Due to the importance of the information service, Geographic Information System should be developed to help users search social facilities and their specific locations in Garut. Web Modeling Language method is expected to help the development of web engineering which can run in web platform to display existing facilities as required, especially in map [6]. Each region in Indonesia has unique potential that should be analyzed to be considered in national development. Analysis was performed by categorizing data of potentials in Indonesia via PPODES 
census, thus consisting of two attributes, i.e. numeric and categorical [7]. In the study by B. T. Nguyen et al (2017) on prediction user movement from historical location data, Movement Predictor application was made to help collect location data from users registered by Global Positioning System (GPS). To analyze various types of feature in comparing three learning models [8]. EGovernance (E-Gov) is generally recognized as an innovation which encourages socio-economic development across the world. Therefore, developed and developing countries continue to try to perform E-Gov projects because they're proven to improve good governance and government services for citizens or society. Developed countries such as Republic of Korea, United States, Singapore, and Denmark have successfully transformed their economies by E-Gov. It's different from countries which have many failed E-Gov projects which didn't develop well [9].

Susanty, et. al. examine the influence of a company on the extent of the assimilation of internet technology into the company's daily operation. The study examined critical success factors adopted by internet technology and the effect of internet technology adoption on company performance [10]. Internet development and current technology offer new opportunities for the government to serve and interact with the public. Previously, E-Government was used to provide better relationship whether from the government or the society. Most governments have realized the importance of ICT and therefore may inhibit the role of E-Government by presenting some challenges by comparing with others, especially developing countries, thus affecting the success rate in E-Government in public service. A study in Kenya to develop success factor and adoption of EGovernment from the society's perspective aims to identify factors and challenges to the success of the implementation of E-Government [11]. It's very important to get better understanding on what's effective in government project management and how to manage project effectively, thus clarifying the definition of government project management, effective government project management standard and the effect of success by critical factor in governance model. A questionnaire in China produces a list of success factors affecting the success in governance quantitatively [12]. According to Alfat, Triwiyatno and Isnanto reliable web-based development of monitoring system of online application media to simplify recapitulation and documentation of temperature and humidity, to accelerate web development, there should be web technology application of the framework. In developing the application, LARAVEL MVC framework is used as scripting method [13].

A study by Kainde, Santoso and Budiyanto shows that Bali is famous as a tourism city in some countries across the globe which makes Bali unique as an Indonesian icon. There are many tourism spots famous for diving which are favored by local and foreign tourists. Geographic Information System was developed to map diving locations in Bali [14][15]. Yogyakarta is also special in Java. Every year, tourists visit Yogyakarta during holiday to visit tourism spots, e.g. Borobudur
Temple, so there should be alternative information in searching tourism location, i.e. mobile web-based Case Based Reasoning application, to determine tourist destination [15][14]. A study by Nugraha, et.al shows that internet and smartphone technology development has changed people's behavior in their daily interactions. People more easily ask for and obtain information via mobile device. This study is used to help tourists get location information in Surakarta. The research result shows that tourists easily and quickly get location information in tourism city Surakarta [16].

\section{Material and method}

Application is run by Framework and method as benchmarks in the current case study.

\subsection{Geographic information system of Boven Digoel}

Geographic Information System in Boven Digoel Regency was developed to realize the vision and missions of the Regent of Boven Digoel in ICT, particularly by application development by the Department of Communication and Informatics of Boven Digoel Regency. In general, GIS was created by many stages and data, and the reviewed location. The Department of Communication and Informatics of Boven Digoel Regency has worked with an educational institution in Yogyakarta to develop human resources and information technology. As a partner in human resources and information technology development, YOGYA EXECUTIVE SCHOOL "YES" has held various national information technology trainings and human resources development joined by representatives of local government agencies, universities, hospitals, schools, SMEs, NGOs and private companies since 2004.

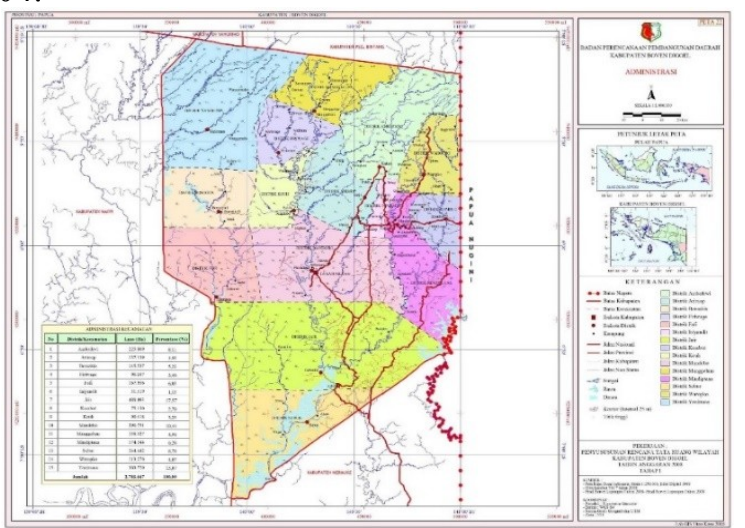

Fig. 1. Geographic Information System of Boven Digoel Regency

(Source : $\underline{\text { http://www.bo vendigoelkab.go.id/halaman/peta }) ~}$ 


\subsection{Critical success factor}

The method was Critical Success Factor which is run for Geographic Information System application of descriptive Data of Local Potentials of Boven Digoel Regency, whether tourism, plantation, and forestry potentials in information and location data of the latitude and longitude in the GIS application. This study was performed systematically, factually and accurately based on the case of the development of Geographic Information in Boven Digoel Regency. Critical Success Factor is an analysis method which considers several critical things in the environment to define factors affecting the success.

In the present study, the authors used Critical Success Factors methods to successfully develop geographic information system application of data of local potential of Boven Digoel Regency, especially in information and location, so that the result of the geographic referenced information can display the correct location to fulfill the needs for local information of Boven Digoel Regency.

\subsection{Laravel}

According to Komara, et. Al. developing generic software application built on web dynamic is complex and expensive because programmer must focus on certain platform, technology and architecture. The programmer should understand the behavior and environment of each platform, technology and architecture. This study was aimed to produce generic pattern generator for web dynamic application for three web dynamic platforms: Java EE, .NET, PHP.

We used MVC (Model-View-Controller) architecture to develop generic pattern. Every layer of MVC was analyzed by their special technology. The explored technologies were: layer view, Java, PHP [17]. Traditional framework design method to design web has many limitations, take a long time, etc. Therefore, this paper presents design and implementation of a web method based on LARAVEL framework. LARAVEL makes standard development process, processes several automatic non-business logical relations. This paper designed and implemented simple LARAVEL model which achieved automatic processing for part of the design, experimental and proven simulation, web design based on LARAVEL framework [18]. Parkar et al (2016) states that in today's era, Internet in widely known. Today, most business processes are online. Companies prefer to send job vacancies in their websites and receive CVs from qualified candidates. Millions of people post their $\mathrm{CVs}$ on the websites. The task of selecting and verifying the CVs are difficult, time consuming, and inaccurate. Therefore, computerization should be considered. In this system, a model or tool extracts information required from qualified candidates. The proposed model uses searching and sorting algorithms [19], evaluating procedure and PHP performance by CodeIgniter and LARAVEL framework. The study was performed because there is a lack of comparison between popular PHP frameworks such as
LARAVEL, codeigniter by php. The results are analyzed and interpreted to expose the performance of the target frameworks [20]. According to Verma View controller (MVC) is architecture in standard design pattern used in website design or web application development. It classifies software applications into three interconnected parts so internal information is separated by information presented or received from users. The main component of the model consists of application data, business rule, logics and functions. The view would be information representation output, such as graph or diagram. Some views of the same information is possible, such as bar chart for management and table interface. The third part, controller, receives input and converts into command for MVC model of LARAVEL Framework which uses PHP programming language [21].

Developing a good application required some tools for support in developing Geographic Information System of data of local potentials of Boven Digoel Regency, whether tourism, plantation, or forestry potential. The framework was Laravel. The programming language was PHP hypertext preprocessor. The model, view and controller of each function are:

- $\quad$ Model

The model serves to store data based on a list of name from database as required. The names which are used will be stored and processed by the system to call between view and controller consistent with application user's input.

- View

The model serves to display HTML of web. As a service for user, view should be designed well to present information for users in terms of color, font, video or picture stored in database.

- Controller

So that application can run in accordance with the procedure, controller function is used. If user wants to display the geography of a tourism potential, the system will display it by calling model and view from database and web interface in HTML.

\subsection{Flowchart system}

As contribution for the authors, data of local potentials are displayed in the developed geographic information system application consistent with the data from the Department of Communication and Informatics of Boven Digoel Regency. This application is based on web in general, providing information to users on data of tourism, plantation and forestry potentials, and the location of the potential. The method was expected to be suitable with the target of the success of the application in promoting its data content and application in the appropriate interface and location so that user can understand the location as an illustration. Figure 2 shows three existing potentials and each of them has different data content consistent with existing potentials in Boven Digoel Regency. 


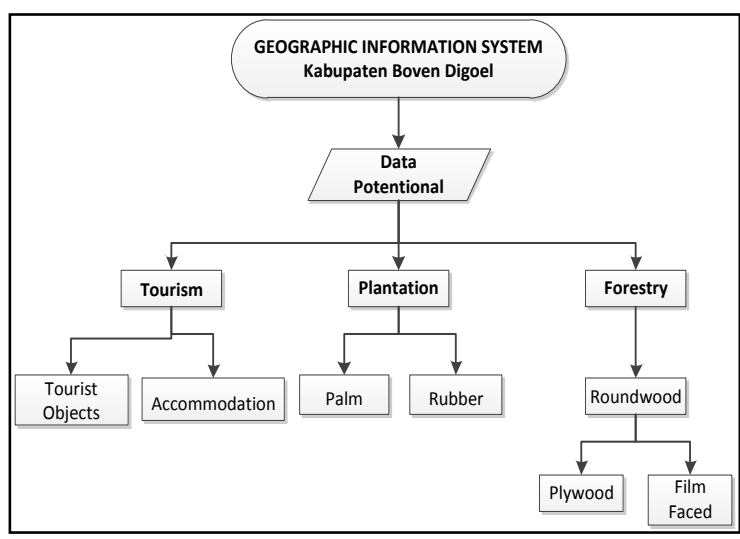

Fig. 2. Flowchart System

\subsection{Use case Diagram}

In this study, the authors' contribution in developing web-based application of data of local potentials is expected to run and be used by users. The system homepage of the application shows web home, tourism, plantation and tourism which contain information on existing potentials and their locations. For management, the application provides a database to store input data in the application so the data managed by the administrator is up to date.

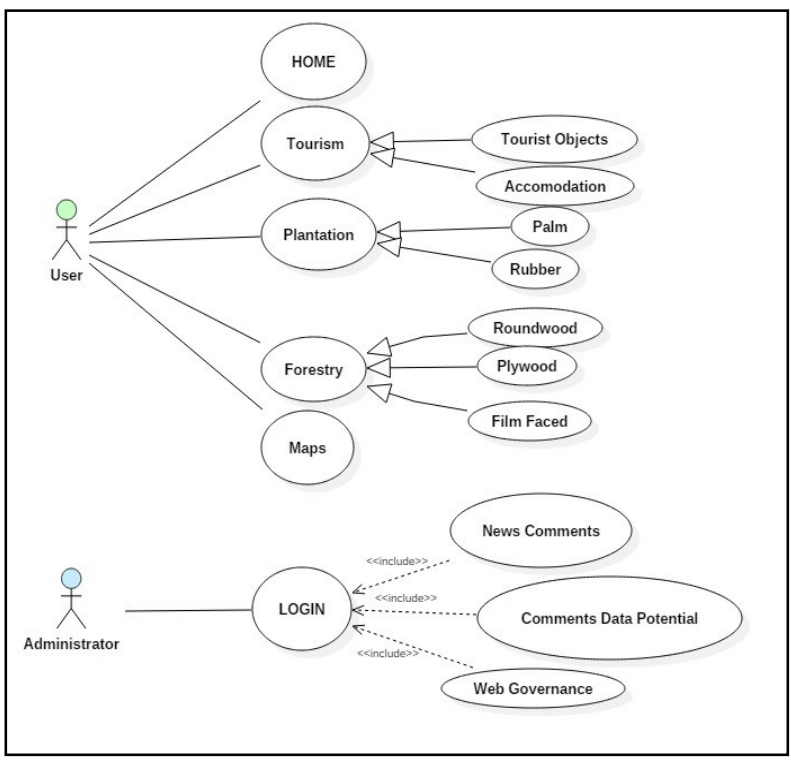

Fig. 3. Use case Diagram

\subsection{Application architecture}

In the architecture of the geographic information system, user can access the website by internet to get information and location. The displayed information is consistent with the data in the database managed by the administrator, so the data is appropriate for user and is published with corresponding and interesting domain. Application can be used using cellphone and computer as required.

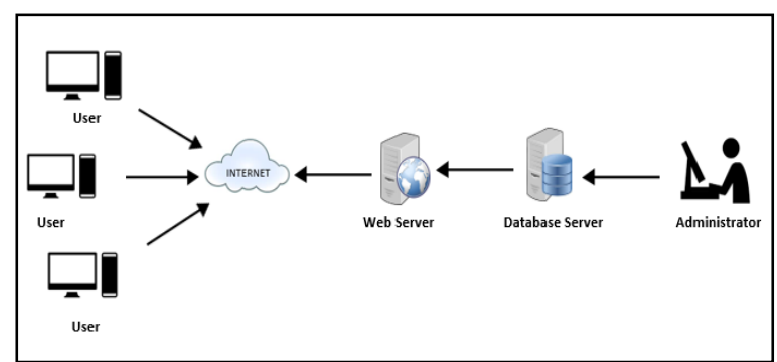

Fig. 4. Application Architecture

\section{Result and discussion}

The web-based geographic information system of data of local potentials of Boven Digoel Regency displays the homepage as the master, tourism objects as references and accommodation as details of tourism potential. The list in the menu bar contains 6 functions of each interface which shows information on the target vision and missions, gallery, map, archive, and contact. The geographic information system application uses CMS Content Management System function so that the display in the website contents of the geographic information system shows header, content and footer.

The header shows the logo and text of the Department of Communication and Informatics along with the moot of Boven Digoel Regency. The menu bar in the application has profile for information on the Department of Communication and Informatics, the government to show this vision and missions of Boven Digoel Regency related to the Department of Communication and Informatics of Boven Digoel, gallery to store pictures related with local potentials, whether tourism, plantation, or forestry. The gallery contains pictures and videos. Map displays the locations of existing potentials by location, archive displays news on local development, especially local potentials. The news are based on data stored in the database which is managed by administrator.

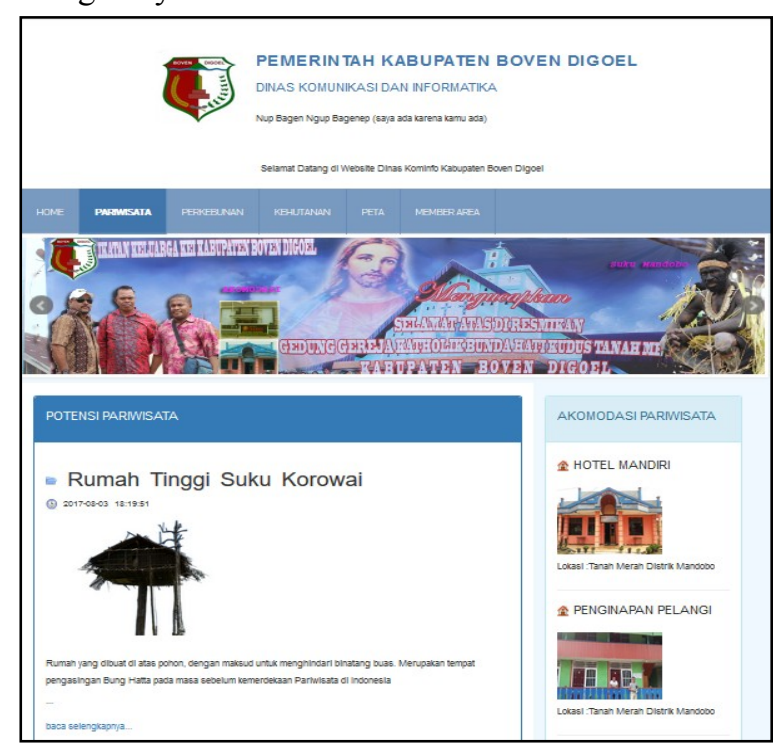

Fig. 5. Tourist Objects Interface 
This page displays tourism object. Every region has its own tourism objects. Boven Digoel Regency has unique tourism objects to visit. The regency is known to be a location for exile during Dutch colonization. The Proclamator was exiled in Tanah Merah city which is now known as Boven Digoel prison. The webpage in the application provides.

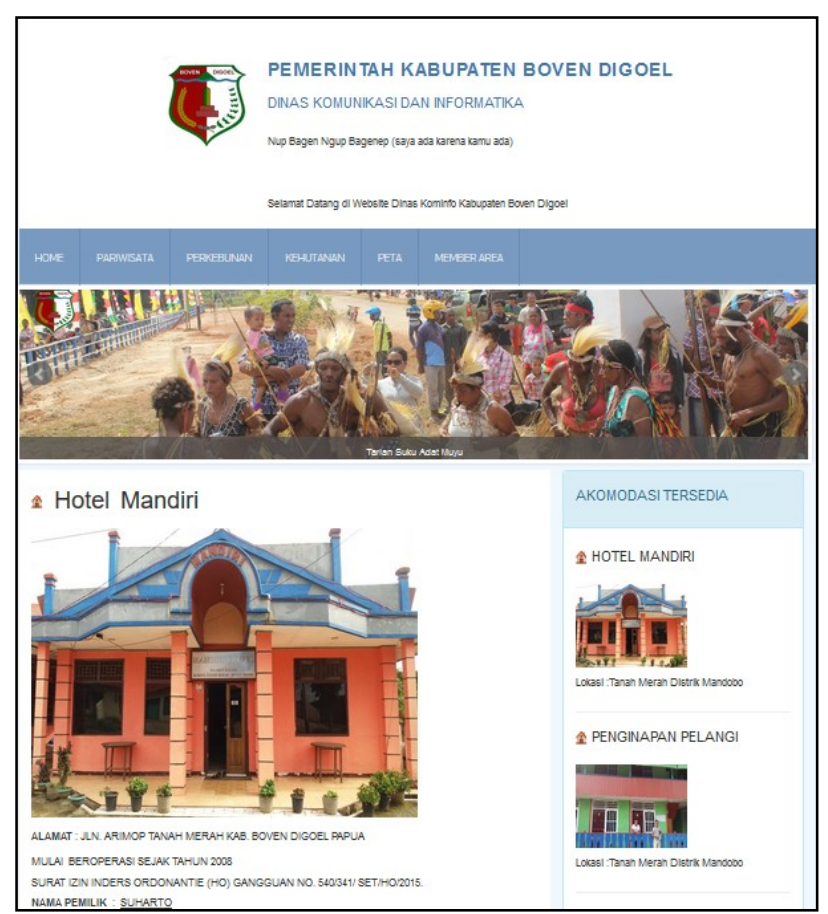

Fig. 5. Accommodation Interface

The accommodation interface displays hospitality services for tourists visiting Boven Digoel Regency as one of Indonesia's historical cities. This interface shows some accommodations services, e.g. hotel, motel, guesthouse etc. and displays gallery of the accommodations, as well as their locations. The information is shown as the information function of accommodation service.

Table 1. Accomodation in Boven Digoel Regency.

\begin{tabular}{|c|c|c|c|}
\hline \multirow{2}{*}{ Business } & \multirow{2}{*}{ Classification } & \multicolumn{2}{|c|}{ Location } \\
\cline { 3 - 4 } & & Lat. & Longi. \\
\hline Idaman & Hotel & -6.1091481 & 140.324523 \\
\hline Mandiri & Hotel & -6.097116 & 140.304465 \\
\hline Boven Jaya & Lodging & $-6,100487$ & 140.309521 \\
\hline Pelangi & Lodging & -6.100871 & 140.303006 \\
\hline Ramayana & Losmen & -6.102172 & 140.306209 \\
\hline
\end{tabular}

To support tourism and other activities in Boven Digoel Regency, there are some businesses which provide accommodation services. Some accommodation business services in Boven Digoel Regency are shown in the following table 1 .

It is can be seen on tabel 2, that beside historical sites, Boven Digoel also has other tourist destinations, i.e. cultural, natural and religious tourist destination
Table 2. Objec Tourism in Boven Digoel Regency.

\begin{tabular}{|c|c|c|c|c|}
\hline \multirow{2}{*}{$\begin{array}{l}\text { Tourist } \\
\text { Objects }\end{array}$} & \multirow{2}{*}{$\begin{array}{c}\text { Kind of } \\
\text { Touris m } \\
\text { Object }\end{array}$} & \multirow{2}{*}{ Area } & \multicolumn{2}{|c|}{ Location } \\
\hline & & & Lat & Longi \\
\hline $\begin{array}{l}\text { Korowai } \\
\text { Tribe's } \\
\text { High House }\end{array}$ & Culture & $\begin{array}{l}\text { Distrik } \\
\text { Yaniruma }\end{array}$ & -5.328406 & 139.823793 \\
\hline $\begin{array}{l}\text { Boven } \\
\text { Digoel's } \\
\text { Jail }\end{array}$ & $\begin{array}{l}\text { Historical } \\
\text { sites }\end{array}$ & $\begin{array}{l}\text { Distrik } \\
\text { Mandobo }\end{array}$ & -6.101513 & 140.299922 \\
\hline $\begin{array}{l}\text { Pesta Ulat } \\
\text { Sagu }\end{array}$ & Culture & Mindiptana & -6.013390 & 140.639266 \\
\hline Gua Maria & $\begin{array}{l}\text { Religy } \\
\text { tourism }\end{array}$ & $\begin{array}{l}\text { Distrik } \\
\text { Mandobo }\end{array}$ & -6.103926 & 140.312294 \\
\hline
\end{tabular}

Table 3. Plantation crop potentials in Boven Digoel Regency

\begin{tabular}{|c|c|c|c|c|c|}
\hline \multirow{2}{*}{ Plants } & \multirow{2}{*}{$\begin{array}{c}\text { Area } \\
\text { Of } \\
\text { Land }\end{array}$} & \multirow{2}{*}{$\begin{array}{l}\text { Rubber } \\
\text { Product }\end{array}$} & \multirow{2}{*}{ Year } & \multicolumn{2}{|c|}{ Location } \\
\hline & & & & Lat & Longi \\
\hline \multirow{5}{*}{ Rubber } & 1.813 ha & 190 ton & 2009 & \multirow{5}{*}{-6.421219} & \multirow{5}{*}{$\begin{array}{c}140.432 \\
360\end{array}$} \\
\hline & 1.913 ha & 220.07 ton & 2010 & & \\
\hline & 2.127 ha & 273.69 ton & 2011 & & \\
\hline & 2.616 ha & 430.92 ton & 2012 & & \\
\hline & $2.811 \mathrm{ha}$ & 383.34 ton & 2013 & & \\
\hline
\end{tabular}

The plantation are dominated by rubber and palm oil. Rubber is people's plantation crops as most people in Boven Digoel Regency cultivate this plant, while palm oil is a large plantation crop managed by companies.

Table 4. The area for palm oil

\begin{tabular}{|c|c|c|c|c|c|}
\hline \multirow{2}{*}{ Plants } & \multirow{2}{*}{$\begin{array}{c}\text { Area } \\
\text { Of } \\
\text { Land }\end{array}$} & \multirow{2}{*}{$\begin{array}{l}\text { Palm } \\
\text { Product }\end{array}$} & \multirow{2}{*}{ Year } & \multicolumn{2}{|c|}{ Location } \\
\hline & & & & Lat & Longi \\
\hline \multirow{5}{*}{ Palm } & 17.268 ha & 22.842 ton & 2009 & \multirow{5}{*}{-6.602175} & \multirow{5}{*}{$\begin{array}{c}140.5015 \\
38\end{array}$} \\
\hline & 17.268 ha & 21.729 ton & 2010 & & \\
\hline & 17.596 ha & 42.307 ton & 2011 & & \\
\hline & 17.648 ha & 32.536 ton & 2012 & & \\
\hline & 17.715 ha & 40.197 ton & 2013 & & \\
\hline
\end{tabular}

It can be seen in tabel 4 that the area for pal oil managed by major companies keeps increasing every year. In 2004, the area was 9.608 hectares, then in 2005 and 2006 it became 10.408 hectares.

Table 5. Product Timber Yearly in Boyen Digoel Regenct

\begin{tabular}{|c|c|c|c|c|}
\hline \multirow{2}{*}{ Company } & $\begin{array}{c}\text { Round } \\
\text { Timber } \\
\text { Product }\end{array}$ & Year & \multicolumn{2}{|c|}{ Location } \\
\cline { 3 - 3 } & & Lat & Longi \\
\hline $\begin{array}{c}\text { Round } \\
\text { Timber }\end{array}$ & $264,322.71$ & 2009 & & \\
\cline { 2 - 3 } $\begin{array}{c}\text { IUPHHK } \\
\&\end{array}$ & $295,484.61$ & 2010 & & \\
\cline { 2 - 3 } IPK & $275,617.19$ & 2011 & \multirow{4}{*}{-6.646954} & 140.7669763 \\
\cline { 2 - 3 } & $121,310,01$ & 2013 & & \\
\hline
\end{tabular}

And the top table is Boven Digoel Regency has large forest with various forest products which can be processed, increasing local income. One of the leading forest commodities is round wood. Below is a figure of the growth of round wood products by IUPHHK and IPK companies. The production of year to year increasing, caused by the businesses producing from the company except in 2013 experience reduction. 
Table 6. Forest product yearly

\begin{tabular}{|c|c|c|c|}
\hline $\begin{array}{c}\text { Forest } \\
\text { Product }\end{array}$ & Company & $\begin{array}{c}\text { Sales } \\
\text { Volume }\end{array}$ & Year \\
\hline \multirow{10}{*}{$\begin{array}{c}\text { Plywood } \\
\& \\
\text { Film Faced }\end{array}$} & \multirow{10}{*}{$\begin{array}{c}\text { IUPHHK } \\
\& \\
\text { IPK }\end{array}$} & 45600 & \multirow{2}{*}{2009} \\
\hline & & 89200 & \\
\hline & & 74513.19 & \multirow{2}{*}{2010} \\
\hline & & 51039.86 & \\
\hline & & 40701.8 & \multirow{2}{*}{2011} \\
\hline & & 120881.13 & \\
\hline & & 38107.56 & \multirow{2}{*}{2012} \\
\hline & & 97760.79 & \\
\hline & & 47174.85 & \multirow{2}{*}{2013} \\
\hline & & 87555.11 & \\
\hline
\end{tabular}

Some forest products are processed and sold abroad, i.e. Plywood and Film Faced. Both forest products started to be sold abroad in 2007 and the sales volumes are shown in the table. In 2007, the sales volume of Plywood abroad was $72.607,01 \mathrm{~m}^{3}$, then declined in 2008 to $45.588,18 \mathrm{~m} 3$.

The present study only displays data of tourism potentials as an example of application interface developed to contribute to the Department of Communication and Informatics of Boven Digoel Regency in developing local development applications for the general public and the people of Boven Digoel. The geographic information system is expected to run and be used.

\section{Conclusion}

The developed application design used Critical Success Factors method to clearly direct the success of geographic information system in displaying the data of potentials as local information, location and promotion for application users to attract people by information on the local potentials of Boven Digoel which is the main objective of the website application. The web-based geographic information system displays information data based on original data from the department of Communication and Informatics of Boven Digoel Regency. Boven Digoel Regency has many local potentials, i.e. agriculture, fishery, mining, and farming. In the present study, the authors only used the data of tourism, plantation and forestry potentials as contribution. It's expected that in the future all existing potentials can be inserted in the web-based geographic information system to be better and usable.

\section{References}

1. T. A. N. Xiaoshan and S. Yizhong, no. 40771164, pp. 183-186, (2010).

2. A. Oudin, D. Sprake, Y. Vagapov, and O. Simonova, pp. 513-517, (2017).

3. L. Wang, Y. Wang, Y. Li, A. Qiu, and K. Tao, 2010 Int. Conf. Web Inf. Syst. Min., pp. 138-142, (2010).

4. A. V. Vitianingsih and D. Cahyono, pp. 0-4,(2016).

5. M. R. Vieira, P. Bakalov, E. Hoel, and V. J. Tsotras, pp. 89-98, (2012).

6. N. Hakim, Maulana and R. Cahyana, J. Algoritm., pp. 1-7, (2015).

7. H. Prasetyo and A. Purwarianti, 2014 Int. Conf. Inf. Technol. Syst. Innov. ICITSI 2014 - Proc., no. November, pp. 13-18, (2014).

8. B. T. Nguyen, N. V Nguyen, N. T. Nguyen, and M. H. T. Tran, Seventh Int. Conf. Inf. Sci. Technol., pp. $1-6,(2017)$.

9. S. Hatsu and E. K. Ngassam, pp. 1-8, (2015).

10. A. Susanty, D. P. Sari, and D. Anastasia, 2016 2nd Int. Conf. Sci. Inf. Technol., pp. 35-40, (2016).

11. I. Otieno and E. Omwenga, pp. 1-9, (2015).

12. W. Xiang, Y. Li, and Y. Shou, no. 71072119, pp. 405-409, (2013).

13. L. Alfat, A. Triwiyatno, and R. R. Isnanto, ICITACEE 2015 - 2nd Int. Conf. Inf. Technol. Comput. Electr. Eng. Green Technol. Strength. Inf. Technol. Electr. Comput. Eng. Implementation, Proc., pp. 46-51, (2016).

14. H. V. F. Kainde, A. J. Santoso, and D. Budiyanto, J. Sist. dan Inform., vol. 11, no. 1, pp. 173-180, (2017).

15. E. K. Dewi, Suyoto, and K. Anindito, Journal in Indonesian, vol. 20, no. semnasIF, pp. 33-40, (2012).

16. B. Nugraha, Nur, Suyoto, and Pranowo, "Mobile Application Development For Smart Tourist Guide," pp. 2475-2481, (2017).

17. H. Komara, B. Hendradja, and P. Saptawati, pp. 15, (2016).

18. H. E. R. E. N. Yu, Int. Conf. Comput. Sci. Electron. Technol. (ICCSET 2014), no. Iccset 2014, pp. 301304, (2015).

19. V. V Parkar, P. P. Shinde, S. C. Gadade, and P. M. Shinde, IOSR J. Comput. Eng., pp. 36-41, (2016).

20. R. Das and L. P. Saikia, Int. J. Curr. Trends Eng. Res., vol. 2, no. 6, pp. 42-48, (2016).

21 A. Verma, Indian J. Comput. Sci. Eng., vol. 5, no. 5, pp. 196-198, 2014. 